\title{
Čiji je kaj? Narječje između prihvaćanja i odbijanja
}

\author{
KRUNOSLAV PUŠKAR \\ Filozofski fakultet Sveučilišta u Zagrebu, Ivana Lučića 3, \\ HR-10000Zagreb, krunoslavpuskar2@gmail.com
}

\section{SCN VIII/2 [2015], 20-35}

Namen prispevka je predstaviti nekaj vidikov hrvaškega kajkavskega narečja. Prvi vidik se nanaša na njegov zgodovinski prikaz: kako je njegova polifunkcionalna knjižna različica $\mathrm{v}$ obdobju oblikovanja hrvaškega naroda in standardizacije jezika marginalizirana v prid druge knjižne različice. Glede na izide njegove marginalizacije avtor zaznava izgubo jezikovne in regionalne zavesti, jezikovnega ponosa in jezikovnega prestiža ter posledično neugoden sociolingvistični status kajkavskega narečja. Drugi vidik obravnava njegove trenutne možnosti: morebitno uvajanje v šole v obliki fakultativnega pouka ali izvenšolske dejavnosti. Tako bi se sociolingvistični status kajkavskega narečja v izobraževalnem kontekstu povečal, zagotovljen bi bil tudi pozitiven odnos do njega, kar je bistveno zaradi trenutno zelo negativnega odnosa tako s strani naravnih govorcev kot tudi tistih, ki niso naravni govorci tega narečja.

This paper considers the Croatian Kajkavian dialect from several perspectives. First it is considered from a historical overview: how its polyfunctional literary variant became marginalised at the expense of another literary variant in the era of Croatian nation-building and language standardisation. Among the outcomes of this marginalisation, the author finds a loss of language and regional awareness, language pride and language prestige, and more generally an unfavourable sociolinguistic status of the Kajkavian dialect which continues to the present day. As a result, the second part of this paper deals with a proposal for the present: the introduction of Kajkavian to schools as part of elective courses or extracurricular activities. In this way, the sociolinguistic status of Kajkavian in the educational context would be improved and positive attitudes towards it ensured, which we consider vital due to its present highly negative perception by both speakers and non-speakers.

Ključne besede: kajkavsko narečje, ideologija standardnega jezika, ekolingvistika, sociolingvistični aktivizem, odnosi do dialektov

Key words: Kajkavian dialect, standard language ideology, ecolinguistics, sociolinguistic activism, attitudes to dialects 


\section{Uvod}

$V$ megli sem videl, videl sem v megli: // seh križneh putov konec i kraj. // V meglenom blatu, v pogrebnom maršu, // otkod nas nigda več nebu nazaj, // Ileri kak pilki, faklonosi, // zaškrabani dijaki, larfonosi, // pokapali su paradno starinsku reč Kaj. // Kak zvon je Kaj germelo, // kak kres je Kaj plamtelo, // kak jogenj, kak harfa vekomaj, // a oberpilko $v$ gali, // s pogrebnom faklom v roki, // med ilerskimi fanti, // mertvečkemi snuboki, /I španceral se // doktor Ludwig von Gay. (Krleža 1973: 104-105)

Poznati stihovi iz Balada Petrice Kerempuha, izvorno izdanih na stotu obljetnicu Gajeva odbacivanja kajkavštine (1936.), čest su primjer povijesne jezične samospoznaje, ali i povijesnih jezičnih perturbacija koje su nepovratno oštetile kajkavski književni jezik. Naime, kajkavski je književni jezik ozbiljno figurirao uz čakavski i štokavski književni jezik da postane osnovicom hrvatskog standardnog jezika zbog svoje izgrađenosti i polivalentnosti, no prvenstveno zbog svog relativno kasnog javljanja (druga polovica 16. st.) i procvata (18. st.) u odnosu na druge književne jezike te ograničenog prostora upotrebe (sjever-sjeverozapad Hrvatske) književna kajkavština ipak nije postala temeljem hrvatskog standarda. Ljudevit Gaj, koji je još kajkavskim književnim jezikom napisao svoju Kratku osnovu (1830.), tako je svojim opredjeljenjem za štokavsko narječje u jeku ilirskog pokreta postavio jezične temelje na osnovi kojih se kroz stoljeća, polako ali sigurno, počinje pisati dugačak nekrolog književnoj kajkavštini. Naravno, taj Gajev postupak nije bio posve bez temelja jer se zbog već spomenutih nepovoljnih geopolitičko-sociolingvističkih uvjeta $\mathrm{u}$ hrvatskim zemljama odabir štokavštine u to vrijeme činio kao najbolje rješenje. Prema Barcu (1954: 103), »[z]adržati kajkavštinu kao književni jezik značilo bi napustiti svaku pomisao na sjedinjenje s Hrvatima čakavcima i štokavcima, sa svima posljedicama, koje bi u tom slučaju nadošle u hrvatskom narodnom životu i književnosti.« Međutim, marginalizacija književne kajkavštine koja je uslijedila imala je za posljedicu slabu afirmaciju kajkavskog narječja uopće u hrvatskom javnom diskursu. Premda je početkom 2015. godine književna kajkavština dobila svoju veliku povijesnu potvrdu time što joj je dodijeljen ISO jezični kôd 639-3 - kjv., kajkavsko je narječje još uvijek uvelike diskriminiran jezični varijetet. ${ }^{1}$

\section{Ideologija standardnog jezika}

Afirmacija nekog varijeteta uvijek ovisi o pretežnoj zastupljenosti stavova o njemu, kako govornika tog varijeteta, tako i negovornika. Prema laičkom poi-

${ }^{1}$ Zanimljivo je primijetiti kako ni čakavski ni štokavski književni jezici još nisu dobili svoj jedinstven jezični kôd. Premda im trenutačno nedostaje potpore za takvo što, vrlo je izgledno da će u doglednoj budućnosti i ti slavenski mikrojezici dobiti svoju službenu jezičnu potvrdu. 
manju jezika, standardu se tako obično pripisuje prestiž, elitizam i superiornost, čime mu se pridaje veća vrijednost nego ostalim varijetetima, dok su dijalekt ili narječje nerijetko obezvrijeđeni jer im, prije svega, nedostaje institucionalna potpora kakvu uživa standard. Dakle, jedina razlika između standarda i ostalih varijeteta jest prisutnost ili neprisutnost institucionalne, a time i društvene, potpore, što u konačnici pridonosi uzvisivanju standardnog jezika i javljanju takozvane ideologije standardnog jezika (Milroy 2001; Lippi-Green 2012). ${ }^{2}$

Premda su standardni jezici uvelike potrebni kao »neutralna« sredstva komunikacije, njihova idealizacija nauštrb drugih varijeteta može samo naštetiti valorizaciji kako jednih, tako i drugih. Naime, opće je poznata činjenica da dijalekti prethode jezičnoj standardizaciji pa oni prema tome imaju jednak jezični potencijal kao i standardni jezici. Također, kako u dijalektima postoji jezična varijantnost, tako se ona javlja i u standardnim jezicima, iako zbog jezičnoga konzervativizma često prevladava stav da standardni jezik ne podliježe varijaciji, odnosno da je on homogen, što nije točno. Kao zaključak svega ovdje navedenog možemo reći da je standardni jezik zapravo jedan od varijeteta istog jezika pa je, shodno tome, hrvatski standardni jezik samo jedan od hrvatskih varijeteta, jednake vrijednosti. ${ }^{3}$ No tome u praksi nije tako. Kako izvrsno zapaža Težak (1997: 14),

[p]ostavši znakom društvenog prestiža, jer su njime suvereno ovladali ne samo obrazovani nego i gospodujući, viši slojevi, jezični je standard potisnuo dijalekt na nižu prečku vrijednosne ljestvice, ostavivši ga za porabu zapostavljenom, neukom puku, kojemu su nejednom dali znati da živi primitivno i govori prosto, pa su mu i dijalekt, ako ga već nisu progonili, ismijavali prepustivši ga tek lakrdiji kao sredstvo za isticanje smiješnosti zatucanoga seljaka ili pogospođenoga sluge.

\section{Stigmatizacija kajkavštine}

Bacimo li širi pogled na hrvatske okvire, uviđamo da je hrvatska kajkavština danas podređena jezična varijanta s izrazito nepovoljnim sociolingvističkim položajem, prema kojem se kajkavsko narječje i njegovi organski govori zbog manjka regionalne svijesti i osjećaja jezične posebnosti smatraju nesavršenim jezičnim oblicima, a sâmi govornici nerijetko vrednuju svoj govor kao nakaradan, nazadan, pa i neinteligentan. ${ }^{4}$ Štoviše, čak i govornici koji svoj govor

${ }^{2}$ Ovdje bih želio zahvaliti prof. Anđelu Starčeviću na tome što me je upoznao s konceptom ideologije standardnog jezika, omogućio mi uvid u njegovu literaturu i dao mi korisne naputke tijekom čitanja cjelokupnog rukopisa u nastajanju.

3 Trudgill (1999) bi zapravo, baveći se standardizacijom engleskog jezika, naglasio kako je standardni engleski jezik samo jedan od dijalekata engleskog jezika.

${ }^{4}$ Upravo je zbog tih i takvih stavova kajkavski izgubio mogućnost relingvizacije, odnosno restandardizacije, iako ima onih koji se još uvijek za to zalažu (usp. Skok 2006). Kako stvari stoje, teško da bi danas i s jakom identifikacijom s kajkavskim narječjem i njegovom simpatizacijom kao samobitnog jezika ispravile »povijesne nepravde« (odnosno potisnutost kajkavskog narječja upravo u doba izgradnja nacija) i pojačala »kajkavska 
tako ne vrednuju, često se u razgovoru jezično prilagođavaju (engl. speech accommodation) svom nekajkavskom sugovorniku, čime zapravo pokazuju manjak osjećaja jezične posebnosti i jezičnog ponosa. ${ }^{5}$ Osim toga, vidljivo je da prilikom javnih nastupa kajkavski govornici pokazuju poprilično sputanu komunikacijsku praksu, jezičnu nesigurnost (engl. linguistic insecurity), tijekom koje nastaje jezični hibrid između organskoga govora i standarda, dok kod nekajkavskih govornika to najčešće nije slučaj. ${ }^{6}$

Uzrok svemu tome jest zasigurno i činjenica da kajkavštinu prati stigma ruralnog jezika na primjeru jezika kultnih Dudeka i Regice. ${ }^{7}$ Stereotipi kajkavske naivčine (ali i velike poštenjačine) i maloga seoskog čovjeka (ali i neobrazovanoga kajkavskoga kumeka) još uvijek su prisutni u određenoj mjeri i baštine se iz naraštaja u naraštaj kod nekajkavskih govornika, što se pak odražava u sputanom javnom govoru kajkavskih govornika. Kraj tim anakronističkim pogledima i predrasudnim fosilima moglo bi ponuditi jedino planiranje prestiža hrvatske kajkavštine koje bi kajkavsku riječ učinilo popularnom poput čakavske riječi, koja je danas zastupljena mnogim popularnim klapama, pjevačima, javnim osobama, ali i velikim osjećajem ponosa kod sâmih govornika. No kako pribaviti prestiž jednome narječju?

\section{4 »Nasilna kajkavizacija crtića« i jezična metropolizacija}

U novije vrijeme pokazan je u javnom diskursu nov pristup kajkavštini i to $\mathrm{u}$ nacionalnim razmjerima. Naime, sve je više sinkroniziranih stranih crtanih filmova u Hrvatskoj koji osim na standardni jezik bivaju djelomično ili većim dijelom prevedeni na hrvatske urbane i ruralne govore. Na primjeru od stotinjak sinkroniziranih stranih crtanih filmova do danas može se zaključiti

stvar«. Prekidom vremenskog standardnojezičnoga kontinuuma kaj je, čini se, odavno izgubio standardnojezičnu utrku, prvenstveno zbog nedostatka osjećaja jezične i regionalne posebnosti kod većine kajkavskih govornika.

${ }^{5}$ Prema Giles et al. (1991) možemo razlikovati konvergentno i divergentno jezično prilagođavanje. Dok bi konvergentno jezično prilagođavanje označavalo oponašanje jezičnih osobina sugovornika višeg društvenog statusa, divergentno bi jezično prilagođavanje pretpostavljalo naglašavanje jezičnih razlika u govoru govornika zbog izražavanja društvenog identiteta, društvene kohezije i jezičnog ponosa. U našem bi se, dakle, primjeru kajkavski govornici koristili konvergentnim jezičnim prilagođavanjem. Za temeljan uvid u teoriju jezičnog prilagođavanja najbolje konzultirati Giles i Coupland (1991) te Giles et al. (1991).

${ }^{6}$ Kako se tvrdnje o jezičnom prilagođavanju i sputanosti kajkavskih govornika, kao i o njihovom negativnom vrednovanju svojega govora, zbog manjka odgovarajućih empirijskih istraživanja ne bi proglasile autorovim subjektivnim dojmom, ovdje apeliramo da se istraži stvarna jezična praksa Hrvatâ kajkavaca.

${ }^{7}$ Moglo bi se reći da je u podlozi svega toga poimanje kajkavskoga govornog područja kao pretežito ruralnog područja s nevelikim društvenim i političkim statusom, zapravo sličan razlog koji je imao i Ljudevit Gaj da se prikloni štokavštini kao standardnojezičnoj osnovici. 
da prisutnost dijalektalne sinkronizacije u nacionalnome medijskome prostoru može povećati prestiž nestandardnoga govora ili sâmoga pogleda na nj, ali i da može uzburkati brojne duhove.

Poznat je, naime, ne tako davan primjer mrežne akcije Roberta Pauletića naziva »Dosta je kajkavizacije u crtićima« iz ljeta 2011. kojom je on pozvao na bojkot određene hrvatske tvrtke za distribuciju filmova zbog, prema njemu, "nasilne kajkavizacije crtića«, a povod mu je bila premijera crtanoga filma Štrumfovi. Pretjerana zastupljenost kajkavštine u tom i drugim crtanim filmovima, prema Pauletiću, samo nanosi štetu djeci iz nekajkavskih krajeva, što zbog nestandardnoga i nepoznatoga jezika, a što zbog negativne portretizacije crtanih likova koji govore čakavštinom, te bi bilo bolje da crtani filmovi nisu regionalno obojeni, odnosno da se sinkroniziraju izravno i izričito samo na hrvatski standardni jezik. ${ }^{8}$ Usprkos Pauletićevim stavovima, moramo ustvrditi da je kajkavština ipak premalo medijski zastupljena (pa tako i u dotičnome crtanome filmu), ali priznajemo da je nacionalno plasiranje nestandardnih govora putem medija osobito delikatna stvar. Kako Žanić (2009: 185) zaključuje, »[m]asovni mediji, posebno sinkronizirani animirani filmovi, u cjelini zaista jesu više posredovali zagrebačke komunikacijske prakse i Dalmaciji i drugim hrvatskim regijama, no time su /.../ zapravo uspostavili svojevrsnu ravnotežu u kategoriji izloženosti varijetetima drugoga « (njegov kurziv). ${ }^{9}$ Također, sigurno je da je standard emocionalno, »konotacijski neutralan i bez konfliktnog potencijala« (Žanić 2009: 74) te »pouzdano sredstvo za bijeg od partikularnog identiteta« (Žanić 2009: 181), no sinkronizacija, pogotovo ako je uspješna, može dati drukčiji, pozitivniji pogled na dijalektalnu raznolikost i izražajnost. ${ }^{10}$

Sve nam ovo pokazuje kako je prisutnost organskih, autohtonih govora $\mathrm{u}$ javnom prostoru ograničena te da su oni zapravo svedeni samo na svoj pravi geografski prostor kao jedini jezični rezervat. ${ }^{11}$ Svako širenje određenoga govora

${ }^{8}$ Unatoč svemu, jako je mala vjerojatnost da će sva djeca zbog gledanja animiranih filmova početi kajkati, prvenstveno zbog toga što su riječi, izrazi i frazemi koji se mogu čuti u crtićima isključivo vezani uz određeni kontekst. Riječi poput fakat, ročkas, ziher itd. izričito zagrebačke provenijencije protiv kojih se Pauletić svim silama bori zasigurno će biti popularne, no one će najvećim dijelom ostati konotacijski povezane uz crtane junake i na taj način kontekstualizirane.

${ }^{9} \mathrm{O}$ problemima sinkronizacije crtanih filmova i čestih portretiranja određenih crtanih likova istim narječjima i govorima, čime se promiču (negativni) stereotipovi o njihovim govornicima i cijelom govornom području, vidi Žanić (2009) u monografiji indikativna naziva Kako bi trebali govoriti hrvatski magarci? O sociolingvistici animiranih filmova. Ta nam monografija na zanimljiv način pokazuje kako se zapravo u jeziku ogledaju promjene ili čak konstante u društvenom ponašanju, kao i jezični odnosi moći.

${ }^{10}$ Sinkronizacije, između ostalog, mogu pomoći djeci, ciljnoj skupini takvih crtanih filmova, da oblikuju svoje vlastite stavove o prezentiranim jezičnim varijetetima. Također, sinkronizacije mogu umnogome utjecati na pozitivno poimanje dječjeg vlastita lokalnoga govora i dovesti do zaključka da on raspolaže daleko većim izražajnim mogućnostima negoli standard.

${ }^{11}$ Međutim, treba priznati da je u novije vrijeme očita ozbiljna jezična ekspanzija metropole. TV programi i drugi mediji sa zagrebačkom adresom poprilično nesmotreno 
izvan svog domicilnog prostora shvaća se pak kao narušavanje tuđeg jezičnog teritorija zbog neposrednog uključivanja tržišnih elemenata jezika. Drugim riječima, jezik se ovdje shvaća prvenstveno kao kapital oko kojeg unatoč svemu uvijek postoji doza sumnje kada se nađe na stranom jezičnom teritoriju.

\section{Kajkavština kroz ekolingvističku vizuru}

Ako bacimo pogled na rasprostranjenost kajkavštine, uviđamo da je postupnim sužavanjem njenog jezičnog i povijesnog obzorja ona svedena na najmanje moguće područje dosada. ${ }^{12} \mathrm{U}$ današnjem uvelike globaliziranom svijetu na jezičnu se raznolikost gleda pretežito pozitivno kao i na biološku, pri čemu je gubitak mnogih jezika i identiteta utjecao na nov i izrazito ekološki pogled na jezičnu raznolikost kao na ekolingvistički sustav (usp. Fill i Mühlhäusler 2001). Prema tom ekološkom tumačenju, koje vuče korijenje još od Augusta Schleichera i njegova poimanja jezika kao organizma, jezični je okoliš iznimno osjetljivo okružje u kojem nametanje jednog jezika nad drugima narušava ravnotežu u čitavom ekolingvističkom sustavu, a potencijalna se lingvistička ekofagija kao takva nikako ne potiče, bez obzira odnosila se ona na koji samosvojni jezik ili pak na sâmo narječje. ${ }^{13}$ Štoviše, potiče se takozvani jezični vitalizam, odnosno inzistiranje na životnoj snazi jezikâ kao prijenosnika znanja i narodnog pamćenja. ${ }^{14}$ Dokidanje jezične ravnoteže značilo bi stoga ozbiljnu eroziju jezika, a time i eroziju znanja te narodnog pamćenja. ${ }^{15}$

promoviraju zagrebački urbani govor i tako provode jezičnu metropolizaciju. Jezična obilježja poput pojave jednoglasnog dinamičkog naglaska (s pretežito ujednačenim mjestom naglaska: gl'ava umjesto gláva) (usp. Kapović 2004), sinkretičkog vokativa (Ej, Marija! umjesto Ej, Marijo!), preferencije prezenta svršenih glagola u službi imperativa (Kupiš mi sladoled! umjesto Kupi mi sladoled!) i futura (Dođem po tebe kad se spremim! umjesto Doći ću po tebe kad se budem spremio!) ili zamjene tipičnog kajkavskog futura futurom I. u zavisnim pogodbenim i vremenskim rečenicama (npr. Doći ću ako ću moći.) (usp. Žanić 2010) najbolji su primjeri jezične metropolizacije i inovacija koje se šire iz hrvatskoga glavnoga grada u svoju periferiju. Kako ustvrđuje Žanić (2010: 121), »došlo je vrijeme povratnog utjecaja neštokavske periferije na rigidno štokavski osmišljen standard «.

${ }^{12}$ Za rasprave o prijašnjim prostorima prostiranja kajkavštine, koji su bili mnogo veći, vidi Lončarić (1996: 149-170).

${ }^{13}$ Prema Davidu Crystalu (2000: 38) zapravo i ne postoji razlika između smrti jezika ili dijalekta: »Smrt dijalekta jest smrt jezika, samo u manjim razmjerima« (njegov kurziv).

${ }^{14}$ Pojam jezik u ekolingvistici podrazumijeva bilo kakav oblik jezika, narječja, govora, varijeteta itd. bez obzira na broj govornika i njegovu zastupljenost. Međutim, kako naglašava Kryżan-Stanojević (2007: 315), »najveći je problem ekolingvistike to da u borbi za očuvanje svojega 'malog' jezika ne zapažamo obližnje jezične entitete koji su od našeg još manji

${ }^{15} \mathrm{~S}$ time u svezi treba još spomenuti pojam etnolingvističke vitalnosti (ethnolinguistic vitality) (Giles et al. 1977: 307-348) koja može biti niska, srednja ili visoka, a koja se može utvrditi na sljedeće načine. Naime, ovisno o trenutnoj jačini institucionalne 
Bilo kako bilo, ekolingvistika, u smislu poticanja jezika da se ne ugasi, ima smisla sve dok sâmi govornici tog jezika inzistiraju na njegovu vitalizmu. ${ }^{16} \mathrm{U}$ suprotnom, ako postoji određena jezična apatija, svaki je pokušaj sprečavanja jezičnog nazadovanja (engl. language attrition, njem. Spracherosion) zapravo suvišan. ${ }^{17}$

\section{6 Čiji je jezik?}

Ako uzmemo sve ove različite i zamršene poglede na jezik, narječja i govore u obzir, lako možemo doći do zajedničkog nazivnika koji se provlači kroz čitav ovaj rad, a to je pitanje: „Čiji je jezik?«. Drugim riječima, tko odlučuje kako će, kada će i što će učiniti s jezikom kojim govori? Hoće li to biti jezični stručnjaci ili sâmi govornici? Zdravorazumski bi odgovor na to pitanje bio: »Pa sâmi govornici!«. Naime, kako zaključuje Matasović (2011: 257), »[j]ezici nisu prirodne sile, već konvencije kojima se ljudi služe u međusobnom sporazumijevanju. A o tome kako će se sporazumijevati, i žele li to uopće činiti, ljudi mogu odlučivati sami.« Međutim, što ako je stav izvornih govornika prema svom govoru izrazito negativan, što ako oni sâmi smatraju da je njihov govor nazadan i nepotreban, što ako ga se srame i on ne pokazuje društveni prestiž, a možda bi morao ili trebao? Trebaju li tada jezični stručnjaci, tj. lingvisti, intervenirati i kako? Prema Kapoviću (2006: 375),

[s]tav se prema dijalektima treba promijeniti ponajprije među jezikoslovcima, a zatim se sociolingvističkim aktivizmom, odnosno javnim djelovanjem jezikoslovaca u medijima, treba utjecati na javno mnijenje i promicati dijalekatnu snošljivost i pozitivan pogled na dijalekte. Važno je uvjeriti same govornike dijalekata da je njihov materinski govor jednako vrijedan kao i standard i da ga se ne smiju sramiti.

Kao što Kapović zaključuje, postoje deficiti u znanju kako kod jezikoslovaca, učitelja, profesora, tako i kod govornika, a dizanjem glasa jezično osviještenih

potpore, društvena statusa i demografske snage pojedine etnolingvističke skupine, može se ustanoviti njen trenutan stupanj etnolingvističke vitalnosti i, u skladu s time, perspektiva da se održi kao zaseban etnolingvistički kolektiv. Pogledamo li kajkavštinu kroz te tri odrednice, možemo zaključiti da ona ima veliku demografsku snagu (naime, otprilike trećina Hrvata su kajkavci), no, kako smo vidjeli u prethodnim pasusima, ona ima i nizak stupanj institucionalne potpore i društvena statusa, čime ne pokazuje veliku perspektivu svoje etnolingvističke vitalnosti.

${ }^{16}$ Umjesto termina »ekolingvistika« neki autori koriste i naziv »preventivna lingvistika«, poput Crystal (2000: 93, 112, 153-154, 159, 161-164).

${ }^{17}$ Postoje i drugi vidovi promjene, odnosno nestanka jezika, kao što su: zamjena jezika (engl. language shift, njem. Sprachwechsel/Sprachverlust) i smrt jezika (engl. language death, njem. Sprachtod). 
pojedinaca može se mnogo učiniti za percepciju i status pojedinog jezika u medijima i javnosti. ${ }^{18}$

Međutim, bez obzira na te novije jezične stavove, neki će pak reći da su ipak došli prekasno. Ozbiljan zamah globalizacije s jedne strane polako utječe na promjenu i gubitak određenih identiteta, a s druge strane ona donosi njihovo jačanje i potvrdu. Neki će pak reći da je globalizacija samo povod za pomamu i lov na identitete kojih nikada nije ni bilo ili koji nikada nisu bili toliko izraženi. Bilo kako bilo, kako odrješito zaključuje Katičić (2010), »[a]ko se identiteti ne mogu suprotstaviti globalizaciji, onda nisu zaslužili da postoje.« No to ne bi bio i naš stav. Upravo zahvaljujući sociolingvistici mijenja se predodžba varijeteta i upravo bi se na tom polju trebalo raditi kako bi se osnažili identiteti i promicala međudijalektalna snošljivost.

\section{Kajkavština na satu Hrvatskoga jezika (i drugih satova)}

\subsection{Promicanje jezične samosvijesti}

To nas dovodi do pitanja jezične samosvijesti i pitanja njezina razvijanja. Trebamo li rezervirati određeni lokalni govor samo za komunikacijske odnose između svojih govornika ili mu omogućiti širi prostor djelovanja na kojem bi se mogao razvijati kako lingvistički, tako i izvanlingvistički? Kako je to ostvarivo? Tim se pitanjima zapravo vraćamo na pojam sociolingvističkog aktivizma i obrazovne institucije kao poligona njegova ostvaraja.

Prije svega treba napomenuti kako u lingvističkim krugovima postoje velike sumnje da formalno obrazovanje može išta promijeniti na planu ugroženih jezika i govora. Naprimjer, prema Žaniću (2007: 357),

[j]ezici, u sažetku, ne postaju ugroženi (ili ‘ugroženi') zato što im manjka službeni status ili zato što se ne uče u školama, nego zato jer se prekida neformalni međugeneracijski prijenos i neformalna potpora u životnoj svakodnevici. Drukčije kazano, nikakva jezična prava nisu zajamčila opstanak, održavanje i razvoj ni jednoga idioma jednostavno zato što to u konačnici uvijek ovisi o tome koji će jezik izvorni govornici odabrati za komunikaciju u obitelji, što pak nijedna institucija ne može nadzirati. Posrijedi su procesi dugog trajanja u visoko složenim društvenim sistemima i jezična politika koja teži za uspjehom mora uzeti u obzir sve aspekte društvenog života, samim tim i sve jezične prakse i stavove svih na koje smjera utjecati. (njegovi navodnici)

S tim pogledima i mi bismo se u načelu složili, pogotovo glede izostanka (potpune) transmisije jezika s koljena na koljeno, no međugeneracijski prijenos jezika danas izostaje upravo zbog manjka službenog statusa i potpore u školama koje bi trebale dati važan impuls odgajanju jezične osjetljivosti kako

${ }^{18}$ Iako Kapović (2006: 381-383) zapravo ne navodi čiji je termin »sociolingvistički aktivizam«, on daje svoju skicu koraka, odnosno faza, koje bi taj termin podrazumijevao. 
djece, tako i cjelokupne javnosti. ${ }^{19}$ Premda bi službeni jezik nastave trebao biti hrvatski standardni jezik, ipak bi se različitim nastavnim pristupima trebala na kajkavskome području osvijestiti i kajkavsko-standardnojezična dvojezičnost na nastavi. ${ }^{20}$

\subsection{Jezična pedagogija i metodika}

No što se time dobiva? Osim već navedene jezične osjetljivosti na nastavi bi se njegovala i jezična tolerancija koja je prijeko potrebna kako za afirmaciju kajkavštine, tako i za afirmaciju drugih idioma. Naime, čest je slučaj da se na nastavi jezične pojave učenikâ koje su dijalektalno obojene sankcioniraju obilježavajući ih kao ružno i nepravilno govorenje, čime se stvara suprotan efekt, ili se pak korištenje dijalektalnih elemenata pripisuje djetetovu stupnju inteligencije (usp. Škarić 1988: 47). Uplaši li se nastavnik djetetove dijalektalnosti i krene omalovažavati njegov idiom u najmanjoj dobi, postoji mogućnost da će se prekinuti emocionalna vezanost za materinski govor i stvoriti averzija, kako prema tome idiomu, tako i prema standardu, koji će se pak smatrati nedostižnim ili čak neprihvatljivim. Tu se postavlja važno pitanje zašto se trivijalizira i, nakraju, odbija lokalni govor, koji se zapravo godinama učio kao materinski jezik? Kalogjera (2003: 171), naime, zaključuje da »naši nastavnici i obrazovani ljudi sve manje gledaju na dijalekte kao na rezervoare jezičnih pogrešaka«, a to bi bilo uistinu lijepo vidjeti i u praksi. Tako bi, ostvarujući kajkavsko-standardnojezičnu dvojezičnost na nastavi, nastavnici zasigurno dali pravi doprinos kognitivnom razvoju pojedinca i osigurali bolju socijalnu integraciju djece. Kako sažeto ustvrđuje Jutronić (2010: 282), »[1j]udi s kojima smo u dodiru važni su jer utječu na naš govor«, a upravo bi naši nastavnici izmijenjujući pozitivna komunikacijska iskustva s učenicima bitno pridonijeli poboljšanju sociolingvističke situacije narječja i lokalnih govora, pa i sociolingvističkih relacija prema sâmom standardu.

No tko bi bili ti nastavnici? Svakako bismo u taj termin uključili sve različitim idiomima pozitivno naklonjene pojedince pedagoge, no idealna situacija bi bila ona koja bi uključivala kroatiste s interesom za dijalektologiju koji bi ujedno bili i jezični pedagozi. Naravno, to je izrazito teško ostvariti, pogotovo zbog toga što ako za to ne postoji pogodna jezična politika ili nastavnikove

${ }^{19}$ Kako i sâma Dorian (1998: 3) uviđa problem, »jako je čest slučaj da jezik bude izravno povezan s ljudima niskog prestiža i njihovim identitetima kojima društvo nije naklonjeno tako da se njegovi potencijalni govornici preferiraju distancirati od njega i prisvojiti koji drugi jezik. Roditelji će u tim slučajevima donijeti svjesnu ili nesvjesnu odluku da ne prenesu naslijeđen jezik svojoj djeci te se tako gubi još jedan jezik«.

20 Članak 6. Zakona o odgoju i obrazovanju u osnovnoj i srednjoj školi (NN 126/12 od 16.11.2012.) donosi sljedeće: »Nastavu i druge oblike odgojno-obrazovnog rada, školske ustanove izvode na hrvatskom jeziku i latiničnom pismu.« Stoga se ovdje postavlja pitanje bi li se nastavnike zakonski teretilo ako bi nastavu organizirali dvojezično, na standardu i kajkavštini, odnosno bi li se morao mijenjati zakon kao preduvjet za dvojezičnu nastavu? 
kompetencije, onda sve, ili barem većina toga, ovisi o inherentnoj motivaciji i profilu učitelja ili profesora hrvatskog jezika. Radi li se o nastavniku-kajkavcu ili nastavniku-nekajkavcu zapravo ne bi trebalo igrati toliko veliku ulogu koliko bi trebala prisutnost njegova interesa za kajkavštinu i pozitivna stava prema njoj. Uspostavljanjem pozitivna odnosa prema lokalnim govorima djece uspostavlja se pozitivan odnos prema sâmoj djeci, a to svakome nastavniku može biti samo plus.

Osim »aspekata« nastavnika važni su i aspekti zastupljenosti kajkavštine u školama. Bacimo li pogled na plan i program nastave Hrvatskog jezika, bilo u osnovnoj $^{21}$ ili srednjoj školi, ${ }^{22}$ možemo vidjeti kako zapravo postoji jako malo i sve manje nastavnog sadržaja kojim je obuhvaćena kajkavština. Zbog prenatrpanih udžbenika, čitanka i školskih lektira drugim nastavnim sadržajem ostaje i jako malo vremena za bavljenje kajkavštinom i lokalnim, odnosno zavičajnim, jezičnim i književnim izričajem. Naravno, koliko će nastavnog sadržaja nastavnik i njegov razred savladati te koliko će »mjesta« napraviti za sadržaje na kajkavštini uvijek ovisi o sâmom nastavniku, no dok se trenutačni plan i program ne promijene u korist kaja, izgledniji je ipak drugi scenarij za bolju zastupljenost kajkavštine, a to su izborna nastava ili izvannastavne aktivnosti, u koje se kajkavštinu očito i »gura«.

Naime, upravo izborna nastava i izvannastavne aktivnosti ostavljaju dovoljno prostora i velike mogućnosti za nastavnikovu kreativnost i bolju organiziranost te zastupljenost kajkavštine. Svakako, za to trebaju dobro promišljeni i

${ }^{21}$ Pobližom analizom dvaju setova čitanki različitih autora za osnovnu školu 5.-8. razreda utvrđeno je očigledno smanjivanje dijalektalnog sadržaja i, usudili bismo se reći, očigledan progon kajkavštine. Analizom aktualnih čitanki 5.-8. razreda ustanovljeno je da se kajkavština javlja samo u 6. i 8. razredu, i to u sve skupa četiri pjesme. Međutim, u sklopu medijske kulture gradivo se 8 . razreda bavi i hrvatskim dijalektima na filmu, među kojima se spominje i igrana TV serija Gruntovčani. Jedna ranije odobrena i upotrebljavana serija čitanki (usklađena s HNOS-om) nudila je već u 5. razredu dvije pjesme na kajkavštini (Zdravo Mariju D. Domjanića i Stric-vujc M. Krleže), u 6. čak pet (Ivanjsku iskricu M. Dolenca Dravskog, Brege I. Jembriha, Badnjak I. Goluba, Mali pot I. G. Kovačića i opet Krležinu Stric-vujc), u 7. dvije (Protuletje v bregaj I. Kutnjaka i Crn-bel F. Galovića), a u 8. razredu četiri (Domjanićevu Bele rože, Galovićevu Lastavice, Galiotovu pesan V. Nazora i Mjesečinu B. Jelušić). Bilo bi dobro napraviti opširniju poredbenu analizu i usporediti sve čitanke, pa čak i one izdane prije 90-ih, kako bi se dobio što bolji uvid u odnos kroatistâ prema dijalektalnom sadržaju.

${ }^{22}$ Analizom trenutačno korištenog seta čitanki za gimnazije utvrđen je bolji odnos prema dijalektalnom sadržaju nego što je utvrđen za aktualne čitanke u osnovnoj školi, no i on je daleko od zadovoljavajućeg. U analiziranoj čitanci za 1. razred gimnazije tako nalazimo na kajkavštini Domjanićevu pjesmu Ciklame, krvave ciklame... i epitaf Slovo za Ivana, a u čitanci za 2. razred gimnazije samo ulomak iz djela Pervi otca našega Adama greh J. Habdelića. Čitanka za 3. razred gimnazije naklonjenija je kajkavštini pa u njoj možemo naći pjesmu P. Štoosa Kip domovine vu početku leta 1831., Lj. Gaja Horvatov sloga i zjedinjenje, A. G. Matošev Hrastovečki nokturno, Galovićeve Crn-bel i Jesenski veter te Domjanićeve Kaj, Bele rože i Megle. U čitanci za 4. razred gimnazije nalazimo samo dijelove Krležinih Balada Petrice Kerempuha. 
osmišljeni preduvjeti i predradnje, a konačan ishod i cilj uključivao bi između ostalog: a) skupljanje jezične, književne i etnobaštine, b) provođenje različitih jezičnih i književnih radionica, c) promicanje dijalektalnog stvaralaštva, d) izradu razlikovnih gramatika itd., čime bi se dokumentirala i poticala slikovitost izraza lokalnoga govora.

\subsection{Razlikovne zavičajne gramatike}

Da bi uvođenje kajkavskog narječja bilo uspješno, trebale bi se obavezno uvesti zavičajne razlikovne (ili još i diferencijalne) gramatike. Svakako, za mnoga mjesta takve gramatike još uvijek ne postoje pa bi zainteresirani nastavnici zapravo trebali poticati učenike da sakupljaju građu i zajedno s njima naprave suvisle i sustavne gramatičke prikaze pojedinih govora. Koristi od takvih pothvata bile bi velike. Kao prvo, motivirali bi se mladi naraštaji da sâmi aktivno istražuju svoje govore i ostale govore u svojoj sredini, a kao drugo, komparativnom bi metodom mnogo naučili o jezičnim kategorijama standardnog jezika.

Štoviše, poredbenom analizom tih dvaju srodnih jezičnih sustava ispravile bi se mnoge česte pogreške u nepoznavanju hrvatskog standardnog jezika oko kojih se i dandanas lome koplja. Naime, mogao bi se prije svega savladati naoko kompliciran odraz jata. Prepoznavanjem duljine kod pojedinih kajkavskih riječi poput bel (bijel) i sneg (snijeg) ili cedilo (cjedilo) i vera (vjera) usvojilo bi se pisanje ije/je, odnosno ako u lokalnom govoru u pojedinoj riječi postoji dugo $e$, znali bismo da u standardu moramo koristiti ije, a u suprotnom njegovu kraću varijantu je. No takvih poveznica ne bi bilo samo na morfološkoj i fonološkoj razini nego na svim razinama. Na leksičkoj bi se razini, naprimjer, mogle obrađivati sakupljene istoznačnice i sličnoznačnice sa standardom, a zbog usustavljenosti razlikovnih gramatika većina se pravila standardnog jezika ne bi trebala učiti napamet nego povezivanjem s lokalnim govorom, koji bi mu služio kao dopuna. Težakovim (1980: 153-154) riječima,

[d]ijete je, u pravilu, naviknuto na fonološki, morfološki i sintaktički sustav svoga zavičajnog govora i ono precizno »osjeća« svaki i najmanji otklon od tog sustava. Polaziti od njegova jezičnog osjećaja znači uzeti u obzir tu njegovu sposobnost $i$ iskoristiti je u planiranju i izvođenju jezične nastave.

Ukratko, nesputanim korištenjem bilingvizma na nastavi hrvatskoga standardnog jezika, uvelike bi se osvijestilo znanje lokalnoga govora, a time i poznavanje sâmog standarda, što bi pak općenito podiglo razinu opće pismenosti. Kako zaključuje Kalogjera (2013: 69),

[d]a se skine stigma, osigura dostojanstvo, a time i očuvanje dijalekta, trebalo bi ga poučavati zajedno sa standardnim jezikom, kontrastivno, supostavljajući oba sustava. Tada bi u javnosti postalo jasno da se radi o dva ponešto različita sustava koja posjeduju svoj potpun lingvistički ustroj i da su lingvistički ravnopravni. 
Primjer prve razlikovne gramatike u nastavi standardnog jezika seže još do 1978. godine, odnosno prvog članka Stjepka Težaka s tom problematikom, svojevrsnog pionira na tom području. Otada jezičari vrlo mnogo pišu o razlikovnim gramatikama, pogotovo u posljednje vrijeme, a osobito Đuro Blažeka (usp. 2003; 2006), no učitelji i profesori hrvatskog jezika još uvijek nisu dovoljno kompetentni u dijalektološkom smislu da bi mogli animirati mlađe naraštaje. Premda izvedbeni plan preddiplomskog studija kroatistike Filozofskog fakulteta Sveučilišta u Zagrebu sadržava hvalevrijedne, instruktivne i poticajne kolegije koji se bave hrvatskom dijalektologijom, tijekom diplomskog studija kroatistike ne postoji posebno usmjerenje s naglaskom na dijalektološku obuku potencijalnih učitelja i profesora hrvatskog jezika koja bi dodatno učvrstila i proširila vrijedna znanja s preddiplomskog studija. Stoga, ako ne postoji određeni intrinzični entuzijazam kroatistâ za dijelektologiju i njihova odluka za specijalistički doktorski studij ili za razna usavršavanja putem seminara, jako će se teško steći potrebna dijalektološka znanja za nastavu usmjerenu na poredbenu metodu prema načelu zavičajnosti.

\subsection{Kada bi se počelo s uvođenjem kajkavštine u škole?}

Budući da bi se za prvu ruku kajkavština uvela kao izvannastavna aktivnost, čime se ne bi dodatno opterećivalo učenike i predviđeni nastavni plan i program, s njom bi se počelo već od nižih razreda osnovne škole, s programima prilagođenima određenom uzrastu. Naravno, učenici bi sâmi odabrali žele li ili ne prisustvovati takvoj nastavi, tj. to bi bio njihov vlastiti izbor, a ne obveza ili konformizam kakav je prisutan na redovnoj nastavi.

Takvo posredovanje lokalnih govora u školskoj jezičnoj praksi trebalo je početi odavno. Naime, neprofitna hrvatska udruga Muži zagorskog srca već je 1997. pokrenula inicijativu za uvođenje kajkavštine u škole, no samo su Krapinsko-zagorska, Međimurska i Zagrebačka županija podržale njihovu inicijativu, i to do danas samo na deklarativnoj razini. ${ }^{23}$ Radi li se tu o neinteresu odgovornih instanci, manjku nastavničkog angažmana ili pak nedovoljnom jezičnom identitetu govornika, teško je reći. Možemo samo zaključiti da je krajnje vrijeme da se obrazovne institucije uključe u promociju lokalnih govora

${ }^{23}$ Udruga Muži zagorskog srca jest udruga s kajkavskim predznakom iz Zaboka koja javno djeluje od 1994. godine. Svojim je djelovanjem ona iznimno mnogo pridonijela promociji i revitalizaciji interesa za kajkavštinu. Uz bogato pokroviteljstvo ona omogućava da se od 17. rujna 2002. svake godine održava već tradicionalni znanstveni skup Kajkavski jezik, književnost i kultura kroz stoljeća, na kojem se, osim o uvođenju kajkavskog narječja u škole na kajkavskome govornome području barem kao izbornoga predmeta, raspravlja o većoj zastupljenosti kajkavskoga na nastavi i konačnome osnivanju Instituta za kajkavski jezik. Zahvaljujući tome skupu i udruzi Muži zagorskog srca izdana su do danas tri bogata i poticajna zbornika radova (Capar et al. 2006; Jembrih 2011a; 2011b). Međutim, treba napomenuti da su se istom tematikom bavili i stručno-znanstveni skupovi u Čakovcu (Hranjec 2000). 
i kajkavštine općenito. Da bi se osvijestila javnost o nužnosti uvođenja kajkavskog narječja u škole, trebalo bi kao prvi korak provesti provizorna istraživanja o kajkavskom jezičnom identitetu na kajkavskome govornome području (usp. Puškar 2015). Time bi se zainteresirali sâmi govornici za cjelokupnu tematiku, a iskristalizirali bi se i njihovi jezični stavovi u vezi s kajkavštinom i kajkavskim lokalnim govorima.

\section{Umjesto zaključka}

Ovaj rad imao je za svoj zadatak prikazati više aspekata kajkavštine. Prvi je aspekt bio njezin povijesni prikaz pa smo u uvodnom dijelu pokazali kako je ilirska odluka za štokavsku osnovicu hrvatskog standarda s vremenom nanijela veliku štetu polifunkcionalnoj književnoj kajkavštini tako što ju je u konačnici marginalizirala. Time je kajkavsko narječje izgubilo plodno tlo za svoju afirmaciju, a njegovi govornici osjećaj jezične posebnosti i regionalne svijesti. Taj nepovoljan sociolingvistički položaj prikazali smo na primjeru jezičnog prilagođavanja i sinkronizacije crtanih filmova, na temelju kojih je očita prisutnost jezičnih stereotipova, ali i nedostatak jezičnog ponosa i jezičnog prestiža. Kao teorijske podloge dotakli smo se uvriježene ideologije standardnog jezika, prema kojoj se standardni jezik prvenstveno putem obrazovnih institucija poima kao varijetet vrijedniji od drugih varijeteta bez društveno-političke potpore, što je u potpunosti krivo. Stoga je drugi aspekt kajkavštine u ovom radu bio prikaz njezina potencijalna uvođenja u škole, bilo kao dijela izborne nastave ili izvannastavnih aktivnosti, kako bi se pomoću načela zavičajnosti povećalo zanimanje za kajkavštinu i povećao njezin prestiž. Uočeno je kako se kajkavština i lokalni govori sve više gube iz nastave, a upravo bi njihova zastupljenost bitno doprinijela kognitivnom razvoju i socijalnoj integraciji djece. Uvođenje kajkavštine uključivalo bi tako a) skupljanje jezične, književne i etnobaštine, b) provođenje različitih jezičnih i književnih radionica, c) promicanje dijalektalnog stvaralaštva, d) izradu razlikovnih gramatika itd., a nastavu usmjerenu prema tim ciljevima trebali bi držati ne samo kroatisti s interesom za kajkavštinu nego i svi ostali jezični pedagozi s pozitivnim stavom prema njoj. Tako bi se pomoću poticajne školske jezične prakse generacijama ostvarivala pozitivna promjena društvene svijesti o kajkavštini i njenim lokalnim govorima općenito.

\section{LITERATURA}

Antun BARAC, 1954: Hrvatska književnost od Preporoda do stvaranja Jugoslavije. Knjiga I. Književnost ilirizma. Zagreb: JAZU.

Đuro BLAŽEKA, 2003: Usvajanje gramatičkih kategorija pomoću učenikova zavičajnoga idioma. Dijete i jezik danas. Učitelj hrvatskoga jezika i učitelj stranoga jezika za 
učenike mlađe školske dobi. Zbornik radova s međunarodnoga stručnoga i znanstvenoga skupa. Ur. Irena Vodopija. Osijek: Sveučilište Josipa Jurja Strossmayera, Visoka učiteljska škola u Osijeku. 108-118.

- -, 2006: Primjena razlikovne gramatike u osnovnoj školi. Kajkavski u povijesnom $i$ sadašnjem obzorju. Zbornik radova s okruglih stolova (znanstvenih kolokvija i skupova) u Krapini 2002.-2006. Ur. Nikola Capar, Alojz Jembrih, Vladimir Poljanec. Zabok: Hrvatska udruga Muži zagorskog srca. 207-210.

Nikola CAPAR, Alojz JEMBRIH, Vladimir POLJANEC, ur., 2006: Kajkavski u povijesnom i sadašnjem obzorju: zbornik radova s Okruglih stolova (znanstvenih kolokvija i skupova) u Krapini 2002.-2006. Zabok: Hrvatska udruga Muži zagorskog srca.

David CRYSTAL, 2000: Language death. Cambridge: Cambridge University Press.

Nancy C. DORIAN, 1998: Western Language Ideologies and Small-Language Prospects. Endangered Languages: Language Loss and Community Response. Eds. L. A. Grenoble, L. J. Whaley. Cambridge: Cambridge University Press. 3-21.

Alwin FILL, Peter MÜHLHÄUSLER (ur.), 2001: The Ecolinguistics Reader. Language, Ecology and Environment. London-New York: Continuum.

Howard GILES, Richard Y. BOURHIS, Donald M. TAYLOR, 1977: Towards a theory of language in ethnic group relations. Language, Ethnicity and Intergroup Relations. Ed. Howard Giles. London: Academic Press. 307-348.

Howard GILES, Nikolas COUPLAND, 1991: Accommodating language. Language: Contexts and Consequences. Pacific Grove, CA: Brooks/Cole Publishing Company. 60-93.

Howard GILES, Nikolas COUPLAND, Justine COUPLAND, 1991: Accommodation theory: Communication, context, and consequence. Contexts of accommodation: Developments in applied sociolinguistics. Ur. Howard Giles, Justine Coupland, Nikolas Coupland. New York: Cambridge University Press. 1-68.

Stjepan HRANJEC (ur.), 2000: Kajkavsko narječje i književnost u nastavi. Zbornik radova sa stručno-znanstvenih skupova u Čakovcu 1996.-2000. Čakovec: Visoka učiteljska škola Čakovec.

Alojz JEMBRIH (ur.), 2011a: Kajkavski u povijesnom i sadašnjem obzorju. Zbornik radova sa znanstvenih skupova u Krapini 2007.-2009. Zabok: Hrvatska udruga Muži zagorskog srca.

- - (ur.), 2011b: Kajkavski u povijesnom i sadašnjem obzorju. Zbornik radova sa znanstvenih skupova Krapina 2010. i 2011. godine. Zabok: Hrvatska udruga Muži zagorskog srca.

Dunja JUTRONIĆ, 2010: Spliski govor. Split: Naklada Bošković.

Damir KALOGJERA, 2003: Bilješke o dijalektu u društvu i u nastavi jezika. Komunikacijska kompetencija u višejezičnoj sredini II: teorijska razmatranja, primjena. Ur. Dunja Pavličević-Franić, Melita Kovačević. Zagreb: Naklada Slap. 171-179.

--, 2013: Dijalekatske promjene i standardni jezici u nekoliko europskih zemalja. Jezik kao informacija. Ur. Anita Peti-Stantić, Mateusz-Milan Stanojević. Zagreb: Srednja Europa-HDPL. 61-71. 
Mate KAPOVIĆ, 2004: Jezični utjecaj velikih gradova. Rasprave Instituta za hrvatski jezik i jezikoslovlje 30, 97-105.

- -, 2006: Dijalekti, standard i sociolingvistički aktivizam. Jezik i mediji-jedan jezik: više svjetova. Ur. Jagoda Granić. Zagreb-Split: HDPL. 375-383.

Radoslav KATIČIĆ, 2010: Srpski jezik nije štokavski. Vijenac 427. http://www.matica. hr/vijenac/427/Srpski\%20jezik\%20nije\%20\%C5\%A1tokavski/ (20. 6. 2014).

Miroslav KRLEŽA, 1973: Balade Petrice Kerempuha. Sarajevo: »Oslobođenje«.

Barbara KRYŻAN-STANOJEVIĆ, 2007: Ekolingvistika u obrani jezičnog identiteta. Jezik i mediji-jedan jezik: više svjetova. Ur. Jagoda Granić. Zagreb-Split: HDPL. 299-307.

Rosina LIPPI-GREEN, 2012: English with an Accent: Language, Ideology, and Discrimination in the United States. New York, NY: Routledge.

Mijo LONČARIĆ, 1996: Kajkavsko narječje. Zagreb: Školska knjiga.

Ranko MATASOVIĆ, 2011: Jezična raznolikost svijeta. Podrijetlo, razvitak, izgledi. Zagreb: Algoritam.

James MILROY, 2001: Language ideologies and the consequences of standardization. Journal of Sociolinguistics 5/4, 530-555.

Krunoslav PUŠKAR, 2015: Čiji je kaj? Istraživanje stavova o kajkavštini. Višejezičnost kao predmet multidisciplinarnih istraživanja. Ur. Sanda Lucija Udier, Kristina Cergol Kovačević. Zagreb: srednja europa, HDPL. 329-348.

Joža SKOK, 2006: Je li moguća i da li nam je potrebna standardizacija kajkavskoga jezika. Kajkavski u povijesnom i sadašnjem obzorju. Zbornik radova s okruglih stolova (znanstvenih kolokvija i skupova) u Krapini 2002.-2006. Ur. Nikola Capar, Alojz Jembrih, Vladimir Poljanec. Zabok: Hrvatska udruga Muži zagorskog srca. 156-163.

Ivo ŠKARIĆ, 1988: U potrazi za izgubljenim govorom. Zagreb: Školska knjiga.

Stjepko TEŽAK, 1980: Gramatika u osnovnoj školi. Zagreb: Školska knjiga.

- -, 1997: Dijalekti i književni jezik. Hrvatski dijalektološki zbornik 10, 9-26.

Peter TRUDGILL, 1999: Standard English: What it isn't. Standard English: The Widening Debate. Eds. Tony Bex, Richard J. Watts. London, New York: Routledge. 117-128.

Ivo ŽANIĆ, 2007: Hrvatski na uvjetnoj slobodi. Jezik, identitet i politika između Jugoslavije i Europe. Zagreb: Fakultet političkih znanosti Sveučilišta u Zagrebu.

- -, 2009: Kako bi trebali govoriti hrvatski magarci? O sociolingvistici animiranih filmova. Zagreb: Algoritam.

- -, 2010: Hrvatski jezik danas (Od povijesne tronarječnosti do trokuta standard - Zagreb - Dalmacija). Povijest hrvatskoga jezika / Književne prakse sedamdesetih. Zbornik radova 38. seminara Zagrebačke slavističke škole. Ur. Krešimir Mićanović. Zagreb: Filozofski fakultet u Zagrebu, Zagrebačka slavistička škola. 103-122. 


\section{ČIGAV JE KAJ? NAREČJE MED SPREJETJEM IN ZAVRNITVIJO}

Namen članka je bil prikazati več vidikov kajkavskega narečja. V uvodnem zgodovinskem delu je prikazano, kako je ilirska odločitev za štokavsko osnovo hrvaškega standardnega jezika sčasoma povzročila veliko škodo polifunkcionalni knjižni kajkavščini, in sicer tako, da jo je na koncu marginalizirala. S tem je kajkavsko narečje izgubilo osnovo za svojo potrditev, njegovi govorci pa občutek jezikovne posebnosti in regionalne zavesti. Ta neugoden sociolingvistični položaj smo prikazali na primeru jezikovnega prilagajanja in sinhronizacije risank, na podlagi katerih je očitna prisotnost jezikovnih stereotipov, pomanjkanje jezikovnega ponosa in jezikovnega prestiža.

Pri teoretični podlagi smo se dotaknili ideologije standardnega jezika, po kateri je le-ta predvsem skozi izobraževalne ustanove sprejet kot varieteta, pomembnejša od tistih brez družbeno-politične podpore. Posledično je drugi vidik kajkavskega narečja njegovo morebitno uvajanje $\mathrm{v}$ šole, bodisi v obliki fakultativnega pouka bodisi izvenšolske dejavnosti, s čimer bi se povečala zanimanje za kajkavsko narečje in njegov prestiž. Zaznamo lahko, da kajkavsko narečje in lokalni govori vse bolj izginjajo iz šolstva, a bi prav njihova prisotnost pri pouku $\mathrm{v}$ veliki meri prispevala $\mathrm{h}$ kognitivnemu razvoju in $\mathrm{k}$ socialni integraciji otrok. Uvajanje kajkavskega narečja bi tako vključevalo: (a) zbiranje jezikovne, knjižne in etnološke dediščine, (b) izvajanje različnih jezikovnih in knjižnih delavnic, (c) pospeševanje narečne ustvarjalnosti, (d) izdelavo razlikovalnih slovnic ipd. Pouk, usmerjen $\mathrm{k}$ tem ciljem, bi morali izvajati ne samo kroatisti z interesom za kajkavsko narečje, temveč tudi vsi drugi jezikovni pedagogi, ki imajo pozitiven odnos do njega. Tako bi se s pomočjo spodbudne šolske jezikovne prakse skozi generacije ustvarjala pozitivna sprememba družbene zavesti o kajkavskem narečju in njegovih lokalnih govorih na splošno. 